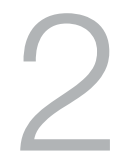

\title{
Working effectively with farmers on agri-environment investment
}

\author{
Graham Fifield
}

\section{Key lessons}

- Agricultural communities are now more diverse than ever, therefore incentive schemes must be flexible, and developed, at least in part, in consultation with the intended audience.

- Less than perfect ecological outcomes may be better than no outcomes at all.

- Voluntary schemes, whether subsidised or incentivised, deliver cost-effective outcomes, but must have ownership by landholders.

- Our largest scheme for private land revegetation was collaboratively developed with landholders and has uptake across the country.

- Environmental change takes time and requires an ongoing commitment to the site and the landholder to guarantee a return on the initial investment.

As a project manager with Greening Australia, I have been fortunate to work with a broad range of farmers and landowners on a variety of restoration and rehabilitation schemes in south east New South Wales and the Australian Capital Territory. This involves frequent collaboration with a range of scientists working in the agri-environment realm. (Indeed, I became involved in natural resource 
management (NRM) by undertaking an Honours Science degree in resources and environmental management at ANU). This experience has given me some overview of the ecological, economic, and social elements of the agri-environment.

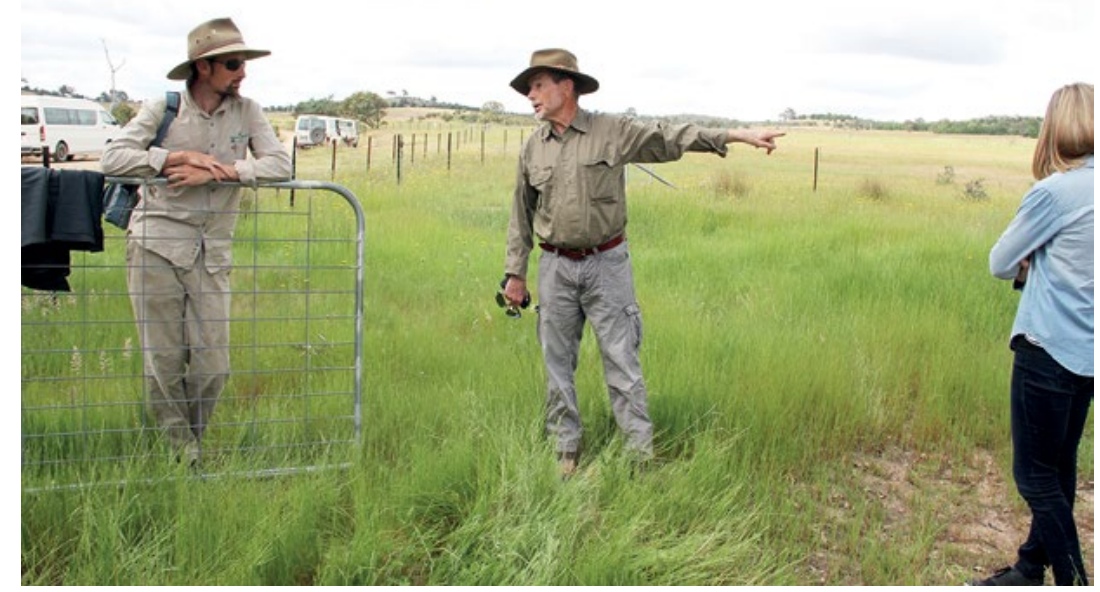

Figure 2.1: Graham Fifield (left) listens to farmer Bob Spiller talking about his experience with Whole of Paddock Rehabilitation.

Source: Photo by David Salt.

It is my opinion that for any agri-environmental program to be effective it needs to acknowledge the diversity of the communities it engages with, and be implemented in such a way as to give ownership to farmers and encourage a voluntary ethic. Feedback from landowners and an understanding of the social barriers to adoption are critical when designing agri-environment schemes because without landholder support, schemes are unlikely to deliver the results desired by funding agencies - a view supported by Vanclay (2011). Furthermore, it is Greening Australia's experience that farmers often supply the innovation that will produce real and enduring results. 


\section{Agricultural communities are now more diverse than ever, therefore incentive schemes must be flexible and developed, at least in part, from the bottom up}

Delivering any agri-environment scheme on private land requires an understanding of the agricultural enterprise, if one is being undertaken, and the social drivers for adoption. That is because these days the description of 'farmer' is an unhelpful stereotype that doesn't encompass the variety of people that are out on the land. The rural demographic is now as diverse as Australia's many unique and wonderful landscapes. Farms come in many forms, from the ever increasing lifestyle farms and peri-urban developments, to the dwindling numbers of traditional family farms as well as the increasing number of corporate agri-businesses. (See Barr 2009 for an overview of the changing agricultural landscape.)

Some of the reasons people get involved with revegetation or conservation programs are to provide shade and shelter for livestock, reduce the impact of soil erosion or salinity, increase birdlife on the farm, provide cleaner water for stock and fish, or to provide free fencing to assist management or as a buffer to adjacent land use. Other reasons have nothing to do with farming or the environment per se, such as for improved aesthetics, to increase property values or simply to block the view of neighbouring houses. Without delivering one or more products or services that the landholder values, we are unlikely to achieve repeat projects or widespread adoption. With this in mind, successful programs are typically those which are devised from the bottom up.

\section{Are less than perfect ecological outcomes better than no outcomes at all? A case study in working with farmers}

Herein lies a challenge: there is often a conflict between the best available science and the expectations of the project's participants. For example, revegetation guidelines for south east Australia 
(e.g. Munro and Lindenmayer 2011; Taws 2007) clearly state that to create habitat for declining or threatened woodland bird species, bigger is better, and revegetation in wider or square configurations is preferable to narrow linear strips. Many farmers, however, desire a long narrow configuration which acts as a windbreak over a large area of paddock, and the perceived loss of agricultural production caused by planting trees over more land is a serious concern. For smaller landholders, wider corridors can simply take up too much land proportional to their holding.

While a 15-metre wide native vegetation corridor with four rows of native trees and shrubs provides habitat for a range of birds, including many of conservation interest, a 25- or 30-metre wide corridor provides habitat for even more. But if we are uncompromising and insist on the best ecological outcome and the landholder isn't willing to forfeit the extra land, we risk achieving no outcomes at all. The question that arises then is: Are less than perfect ecological outcomes better than no outcomes at all?

If the demand for incentive schemes exceeds the capacity to supply, then, yes, we can prioritise towards the best environmental and most cost-effective outcomes. Over 30 years, however, Greening Australia has seen the benefit of working with willing and early adopters and getting early runs on the board. The value of a demonstration site that can be seen by others cannot be underestimated. To continue the wildlife corridor example, the benefits of having corridors on farms, such as improved stock shelter and increased birdlife, were demonstrated in an era where planting trees was considered radical. Incrementally, the next generation of corridors became progressively wider. The cost of fencing was the same regardless of width, so the desire to increase the shelter and wildlife benefits increased, and the loss of productive land became less of a concern. Locally, we have seen the transition from one- and two-row revegetation corridors in the early 1990s, to 12 metres wide, to 15 metres, and now it is generally accepted to create 18-, 20- or even 25-metre-wide corridors. 


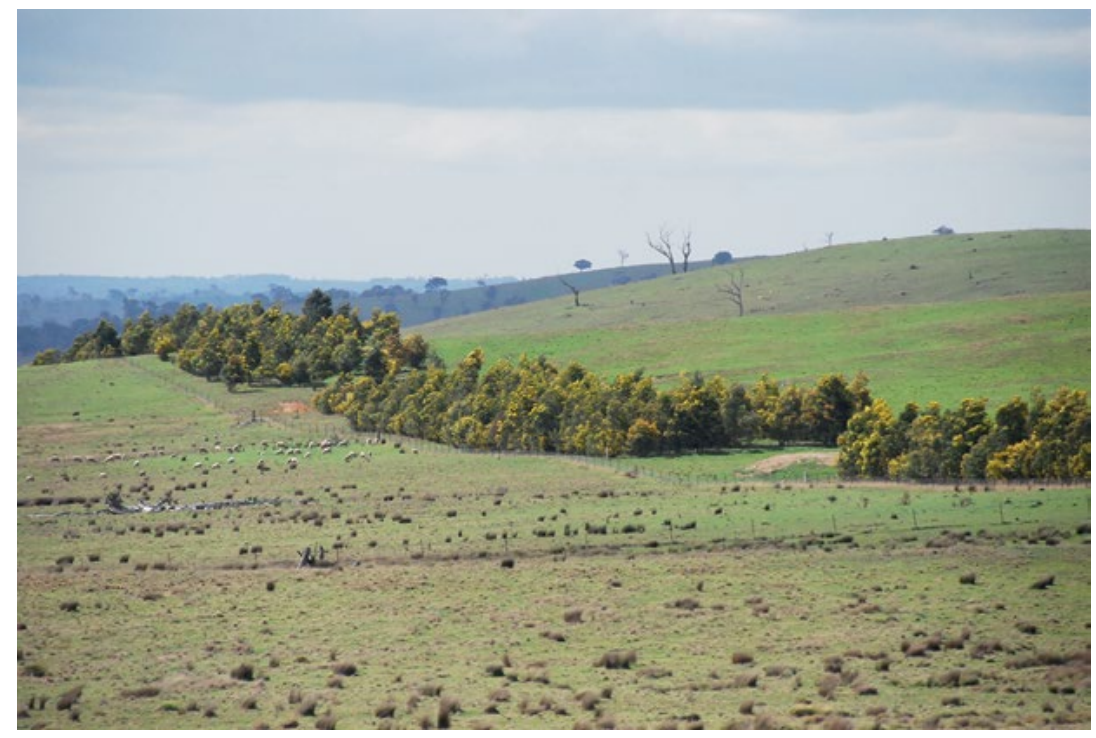

Figure 2.2: Over time, landholders have increased the size of their linear plantings.

Source: Photo by Dean Ansell.

Locally, the demand for these native vegetation corridors, even in the wider configurations, now exceeds our capacity to supply it's a nice problem to have. I would suggest that if we had insisted on 20-metre wide corridors in the early 1990s, we would not have gained the necessary traction within the agricultural community to be in the position we are in now. There are still those landholders, however, often positioned in key locations for habitat connectivity, who insist on the current minimum width of 18 metres. With the tradeoffs between the best available science and prioritising cost-effective actions described above, would you fund these?

In the case that supply exceeds demand for project funding, we typically seek to work with early adopters and innovators. These are often members of local Landcare groups. Further advertising may then be required to attract broader participation in a program. It is interesting to note that delivering projects in a region where Greening Australia has not had a strong or continuous presence often follows this path, highlighting the value in regional staff, regional offices, and a connection to regional areas. 


\section{Voluntary schemes, whether subsidised or incentivised, deliver cost-effective outcomes, but must have ownership by landholders}

As a non-government organisation, Greening Australia is reliant on voluntary and incentivised schemes to achieve environmental outcomes on private land. Whilst Greening Australia does not have a legislative stick at its disposal, as agencies do, neither does it have to satisfy the same expectations regarding accountability. This has enabled Greening Australia to develop an incentive framework that appeals to landholders where ownership and personal investment (often sweat equity) ${ }^{1}$ are required in the project, but the agreements are simple, concise, and not legally binding. The investment of time, money, and/or labour by the landholder is thus invested in their project and it is valued accordingly. It is our experience that, without this investment, environmental outcomes are easily compromised stock enter exclusion areas, planted trees die, and electric fences stop working. In short, they have a stake in ensuring their project works.

Here are a few examples:

1. The establishment of linear vegetation corridors. Also known as windbreaks or wildlife corridors, the establishment of native vegetation in multiple rows along an existing fence line is now a feature of the agricultural landscape. Through corporate or government funds, Greening Australia disseminates a cash payment to the farmer to purchase the materials for the new fence to exclude stock. Importantly, he or she then builds the fence, or pays a contractor to complete the job. One of the best and longest running examples of this style of project is GreenGrid (a partnership between Transgrid and Greening Australia, see www.greeningaustralia.org.au/partner/transgrid). The new vegetation may be established by planting tubestock or by direct seeding. Tubestock are supplied free of charge from the Greening Australia nursery, but the landholder is responsible

1 An interest in a property earned by a tenant in return for labour towards upkeep or restoration. 
for the site preparation and planting. Conversely, direct seeding is carried out by experienced Greening Australia staff while the landholder is responsible for site preparation. Their share of input to the project - whether it be labour, materials, time, or cash is approximately 50 per cent.

2. Protection of rivers, creeks or existing native vegetation. Commonly known as fencing incentive programs, Greening Australia provides funds to the farmer to buy fencing materials. Again, the farmer is responsible for erecting the fence. In the case of rivers, payments towards alternate water sources, such as pipes and troughs, are available. The installation of this infrastructure is up to the farmer. Rivers in Australia are commonly invaded by woody weeds, and in the temperate zone these are typically willows (Salix sp.). Removal of mature willow trees is performed by contractors with heavy machinery and is funded through Greening Australia, with the smaller follow up infestation control performed by the landholder. Both parties have considerable input into the project. (See the Rivers of Carbon project at: riversofcarbon.org.au/.)

3. Whole of Paddock Rehabilitation (WOPR, pronounced 'whopper' — see Fifield et al. 2014). In 2008, Greening Australia launched a new style of incentive scheme that combines traditional revegetation incentives, such as fencing and revegetation, with fixed-term stewardship payments to offset the loss of agricultural production during a short period in which native vegetation is established and matures. The payment has been deliberately set at a rate that is less than the full productive potential of agriculture (typically 30-60 per cent, depending on soil type) thus requiring an additional investment by the farmer into the project. Once trees and shrubs are sufficiently established, typically after five years, agricultural production resumes and the stewardship payments are stopped. Direct seeding and fencing (where occasionally required) follow the models described above. Approximately 3,000 hectares of productive agricultural land within the threatened Grassy Box Woodland communities of temperate Australia have now been revegetated and productively enhanced using this approach. WOPR is also a great example of innovation. Passive tree regeneration schemes with similar payments to landowners exist in Victoria (the Bush Returns Project described by Miles 2008). 


\section{Our largest scheme for private land revegetation was devised by landholders and now has uptake across the country}

Farmers are fantastic innovators; working with them and respecting their knowledge and skills can result in excellent outcomes. A good example of such collaboration can be seen in WOPR.

WOPR grew out of an experiment between a couple of local farmers and Greening Australia in south east NSW. In 1989, following bushfires and an alarming rise in the water table, a paddock on one of these farmer's properties became waterlogged, salty, scalded, and provided little agricultural productivity. The landholder contacted Greening Australia and the phenomenon was identified as dryland salinity.

In 1994, the farmer decided to sow native trees and shrubs across this paddock to combat the high water table. The design was to sow alleys of trees, comprising four rows of trees and shrubs separated by 30-50 metres of pasture for grazing between each alley. The wisdom of this became clear after four or five years when sheep were reintroduced to graze amongst the trees. The widely spaced tree alleys didn't suppress grass growth over large areas of the paddock, while providing shade, shelter, additional fodder, and lowering the water table. Anecdotally, the rest from grazing benefited the native perennial grasses, which were able to grow unhindered and set seed. Areas that were bare and scalded stabilised. The diversity of trees and shrubs provided valuable habitat, and birds that hadn't been seen on the property for many years returned to the area.

WOPR is essentially a form of alley farming, as described by Lefroy and Stirzaker (1997). Greening Australia has refined the scheme over several years to include stewardship payments, and by adjusting the design and seeding rates to strive for the best social, agricultural, and ecological outcomes. Several iterations of the program have been undertaken with money from a variety of sources. In every case, the scheme was readily accepted by farmers because it was easy for them to incorporate into their farm budget. Paddocks were a unit of production, Greening Australia was a trusted partner, and the scheme did not involve legal contracts or involve heavy transaction costs. WOPR agreements simply give the farmers half of the stewardship 
payment up front and half at five years, if the farmer has met their side of the bargain - not putting sheep in. Since the project's inception in 2008, approximately 85 per cent of landholders have qualified for the second stewardship payment. The remaining 15 per cent of projects have typically been cancelled due to poor plant establishment rather than deliberate stock grazing. It is worth noting that when properties have changed owners, the second stewardship payment, which is available to the new owners, has provided the incentive to continue with the stock-free period and thus contributed to the success of the project.
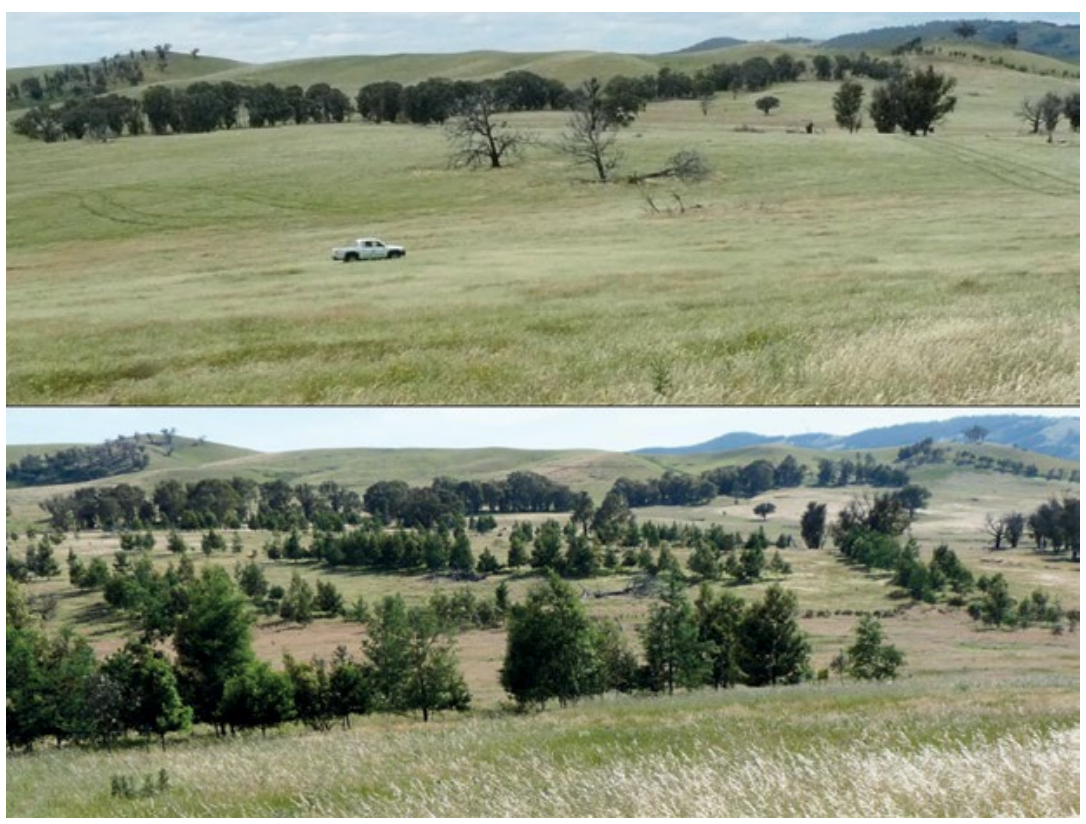

Figure 2.3: A before and after photo of a WOPR project near Bookham, NSW.

Source: Photo by Graham Fifield.

WOPR is now being implemented at a larger scale, with Greening Australia receiving significant grants from the federal government's Caring for Our Country (CfoC) program in 2011 and the Biodiversity Fund in 2013 to run region-wide programs across several catchments in south east NSW. A variation of the program is now being delivered in the Avon valley of Western Australia and is being considered across several states and territories of Australia. 


\section{Environmental change takes time and requires an ongoing commitment to the site and the landholder to guarantee a return on the initial investment}

Greening Australia has planted many trees in its time and delivered many great environmental outcomes. (For examples, see Briggs et al. 2008; Spooner et al. 2002 — remnant fencing; Gould 2013; Higgisson 2014 - riparian restoration; Taws 2007; Lindenmayer et al. 2012 birds in revegetation; Gibson-Roy et al. 2010 - grassland restoration). But possibly a greater impact has been achieved in the relationships and knowledge it has established in the farming community. Restoration takes time, trees grow slowly, so it's important to nurture long-lasting relationships with the landowners who are participating in the various agri-environmental schemes being run around the country. Unfortunately, it is not enough to simply throw a few handfuls of seed over the land and walk away. There will be many challenges facing the landowner with the project over the years, so follow up and being available to provide advice is essential.

A major issue with some government agri-environment programs is that once the program has concluded - and they rarely run longer than a few years - landowners don't have anyone to provide them with advice or feedback on what they should do when problems arise. This may be exacerbated by the loss of NRM staff to state agencies (Curtis et al. 2014). This is where non-government organisations such as Greening Australia and various catchment management groups play an essential role (see Chapter 5 by David Freudenberger). Follow up visits are a challenge, as they are never directly funded, but rather have to be conducted while delivering other projects or from organisational surpluses.

Issues that may arise with project sites are, of course, varied and may include such issues as 'my direct seeding hasn't worked', 'the erosion is still occurring', or 'what should I do about this troublesome animal/ plant?'. Without subsequent advice, it is possible that livestock may be allowed to enter the site and graze on the tiny seedlings, 
that the erosion continues to occur, or that a noxious plant or animal compromises the success of the project. In each case, the investment of public and private time, money, and resources is jeopardised.

Of course, this ongoing relationship is essential for Greening Australia too, and is a necessary investment. One of the challenges in environmental restoration is predicting the trajectory of a site in five, 10 or 100 years into the future. It is only by carefully recording what actions are undertaken today and checking what the site looks like tomorrow that we can begin to learn and adapt our methodology for the best social, ecological, and agricultural outcomes.

\section{Acknowledgements}

I need to acknowledge my colleagues at Greening Australia, past and present, for developing and nurturing the programs and culture that persists to this day. These include, but are not limited to, Bindi Vanzella, Angela Calliess, Lori Gould, Sue Streatfield, Nicki Taws, and Brian Cumberland.

We are indebted to many local landholders, in particular Leon Garry and John Weatherstone, for their innovative paddock-scale solutions to paddock-scale problems.

Thanks to the detailed comments provided by reviewers David Freudenberger and David Duncan.

\section{References}

Barr, N. (2009) The house of the hill: The transformation of Australia's farming communities, Land and Water Australia, Canberra.

Briggs, S.V., N.M. Taws, J.A. Seddon and V. Vanzella (2008) ‘Condition of fenced and unfenced remnant vegetation in inland catchments in south-eastern Australia', Australian Journal of Botany 56(7): 590-9.

Curtis, A., H. Ross, G.R. Marshall, et al. (2014) 'The great experiment with devolved NRM governance: Lessons from community engagement in Australia and New Zealand since the 1980s', Australasian Journal of Environmental Management 21(2): 175-99. 
Fifield, G., S. Streatfield and C. Ross (2014) Introducing Whole of Paddock Rehabilitation: A new approach to regreening the farm, Greening Australia, Canberra. Available at: www.greeningaustralia.org.au/ uploads/knowledge-portal/ACT_WOPR_brochure_2014.pdf.

Gibson-Roy, P., G. Moore, J. Delpratt and J. Gardner (2010) 'Expanding horizons for herbaceous ecosystem restoration: The Grassy Groundcover Restoration Project', Ecological Management and Restoration 11(3): 176-86.

Gould, L. (2013) Analytical case study of a large scale riparian rehabilitation project from an NRM perspective: Boorowa River Recovery, Masters final report. Available at: www.riverfoundation. org.au/admin/multipart_forms/mpf__resource_310_8 Boorowa \%20RR\%20Evaluation\%20Gould\%202013.pdf.

Higgisson, W. (2014) An evaluation of riparian restoration: A case study from the Upper Murrumbidgee Catchment, NSW, Australia, Honours thesis, Institute for Applied Ecology, University of Canberra.

Lefroy, E.C. and R. Stirzaker (1997) Alley farming in Australia: Current research and future directions, CSIRO Centre for Environmental Mechanics, Canberra.

Lindenmayer, D.B., A.R. Northrop-Mackie, R. Montague-Drake, et al. (2012) 'Not all kinds of revegetation are created equal: Revegetation type influences bird assemblages in threatened Australian woodland ecosystems', PLOS ONE 7(4): e34527. DOI:10.1371/ journal.pone.0034527.

Lovett, S. and G. Lori (2015) Rivers of Carbon. Available at: riversofcarbon.org.au/.

Miles, C. (2008) 'Testing market based instruments for conservation in northern Victoria', Integrating Conservation and Production: Case Studies from Australian Farms, Forests and Fisheries (eds T. Lefroy, T. Bailey, G. Unwin and T. Norton), CSIRO Publishing, Canberra, pp. 133-46.

Munro, N. and D. Lindenmayer D. (2011) Planting for Wildlife: A practical guide to restoring native woodlands, CSIRO Publishing, Canberra. 
Spooner, P., I. Lunt and W. Robinson (2002) 'Is fencing enough?: The short-term effects of stock exclusion in remnant grassy woodlands in southern NSW'. Ecological Management and Restoration 3(2): 117-26.

Taws, N. (2007) Bringing back birds: A glovebox guide, Greening Australia, Canberra.

Vanclay, F. (2011) 'Social Principles for agricultural extension in facilitating the adoption of new practices', Changing land management: Adoption of new practices by rural landholders (eds D. Pannell and F. Vanclay), CSIRO Publishing, Canberra. 
This text is taken from Learning from agri-environment schemes in Australia: Investing in biodiversity and other ecosystem services on farms, edited by Dean Ansell, Fiona Gibson and David Salt, published 2016 by ANU Press, The Australian National University, Canberra, Australia. 